\title{
The Influence of Embeddedness of Socio-Economic Status and Self- Control on Consumptive Behavior of Students (at MA Khazanah Kebajikan Ciputat)
}

\author{
Kharisma Danang Yuangga ${ }^{1}$, Neneng Susanti ${ }^{2}$ \\ -Universitas Pamulang, ${ }^{2}$ Universitas Widyatama \\ E-mail: danangyuangga@gmail.com
}

Received: April-2019; Reviewed: May-2019; Accepted: Juny-2019;

Avalaibel Online: August-2019; Published: September -2019)

This is an open access article distributed under the Creative Commons Attribution License CC-BY-NC-4.0 @2019 by author (https://creativecommons.org/licenses/by-nc/4.0/)

\begin{abstract}
In Economic Sociology, social attachment is something that cannot be denied, especially in economic behavior. The purpose of this study was to determine the embandedness of socio-economic status and self-control of the consumptive behavior of students at the MA Khazanah Kebajikan Ciputat. The method used is descriptive method with an associative approach. The sampling technique used was proportional random sampling using the method of saturated sampling technique with a sample of 73 respondents. The analysis tool uses validity test, reliability test, classic assumption test, regression analysis, correlation coefficient analysis, coefficient of determination analysis and hypothesis testing. The results of this study are the embandedness of socio-economic status has a positive and significant effect on the consumptive behavior of students by $41.7 \%$. Hypothesis testing is obtained $t_{\text {count }}>t_{\text {table }}$ or $(7.133>1.994)$, so that $\mathrm{H} 0$ is rejected and $\mathrm{H} 1$ is accepted, meaning there is a positive and significant influence between the embandedness of socio-economic status on the consumptive behavior of students at MA Khazanah Kebajikan Ciputat Office. Self-control has a positive and significant effect on student consumptive behavior by $40.2 \%$. Hypothesis testing is obtained $t_{\text {count }}>t_{\text {table }}$ or (6.906> 1.994) so that $\mathrm{H} 0$ is rejected and $\mathrm{H} 2$ is accepted meaning that there is a positive and significant influence between self-control on the consumptive behavior of students on. A simultaneous test of the embandedness of socio-economic status and self-control has a positive and significant effect on the consumptive behavior of students with a contribution of $48.4 \%$, while the remaining $53.2 \%$ is influenced by other factors. Hypothesis testing obtained the value of $\mathrm{F}_{\text {count }}>\mathrm{F}_{\text {table }}$ or (39.814> 2.740), thus Ho is rejected and $\mathrm{H} 3$ is accepted. This means that there are positive and significant simultaneous influences between embandedness of socio-economic status and self-control on the consumptive behavior of students at the MA Khazanah Kebajikan Ciputat.
\end{abstract}

Keywords: Embeddedness; socio-economic status; self-control; consumptive behavior of students

\section{INTRODUCTION}

In economic sociology, social attachment is something that cannot be denied, especially in economic behavior (Azwar, 2013; Mulyadi, 2018; Sohaimi, 2011; Vyas \& Kumaranayake, 2006). This attachment influences the pattern of human behavior in meeting needs and 
socializing with people around. One of them is consumptive behavior. Excessive tendencies are part of consumptive behavior, wasteful lifestyle is one of the negative impacts (Anggraini \& Santhoso, 2019; Kanserina, 2015; Sari, 2015; Suminar \& Meiyuntari, 2016). Because someone who is accustomed to wasteful in general no longer thinks of tomorrow or the day to come and is more focused on satisfying desires than needs (Sunarsi \& Kusjono, 2019). Consumptive behavior is individual behavior that consumes the production of other parties in the form of services and goods that are not needed excessively to achieve satisfaction as desired or not become a basic need (Astuti, 2013; Fattah, Indriayu, \& Sunarto, 2018; Haryani \& Herwanto, 2015; Sebayang, Yusuf, \& Priyatama, 2011). In essence, those who behave in a consumptive manner always follow their desires, although those desires can later make someone forget to meet their needs, and this is very easily seen in students (Hartati, Martini, \& Winarko, 2019; Hasanah, 2007; Wati \& Suyanto, 2016; Zaroh \& Lukitianingsih, 2014).

Students are a group of young consumers who have unique characteristics such as being easy to follow trends and fashions, easily being persuaded by advertisements and seduction of sellers, not thrifty, less realistic, romantic and impulsive. In this age range, choices, activities, friends, and appearance are often important things to be socially acceptable (Anisa, 2017; Samio, 2018; Suparmin, 2012). The next result is that many students often get entangled in consumptive behavior. With all its uniqueness, students in consuming goods or services more often forget their needs and follow their desires more. This phenomenon is seen from the goods owned by students. Many students are found using accessories such as bags and branded shoes or sophisticated gadgets complete with additional features that are no less expensive. Even though to buy these items rationally, Students are not yet able or unable to buy these items.

According to (Anggraini \& Santhoso, 2017) factors that influence young people's consumptive behavior include; media: television, internet (shopping via the internet, business via the internet and so on); parents: in this case concerns the mental attitude of parents. For example, some cases that are often found by many parents who live with high prestige, it is transmitted to their children so that they are indirectly indoctrinated to have a consumptive lifestyle; society: the mental attitude that develops in the community, in this case, the mental attitude does not want to be left behind by other people, for example other people have new things so they also want to have new goods. 4) Peer: depends on the child in choosing friends; religion: children who grow up in families that have a strong religious foundation will have a feeling and attitude "enough" so that they do not always feel inadequate and lacking from others; Intercourse: depends on how and where someone chooses the social environment or circle.

MA Khazanah Kebajikan is a secondary school located in Pamulang. Being in a strategic location with a lot of hangout places and shopping centers that are not difficult to reach, raises the attachment between the social environment and student consumptive behavior. Usually, after school, they are often stopped by cafes or shopping centers where teenagers gather to just hang out or hang out with friends. This has become one of their factors to be consumptive.

\section{METHOD}

The type of data used is quantitative with primary data sources by distributing questionnaires which are then carried out tabulation and feasibility analysis as well as secondary data from the various scientific literature. The population in this study were MA Khazanah Kebajikan Ciputat students, totaling 270 students. Sampling was used by the Slovin formula technique with an error rate of $10 \%$ to obtain a sample of 73 students. The instrument testing uses validity and reliability tests. From the validity and reliability test stated valid and reliable, this is evidenced by the value of $r_{\text {count }}>r_{\text {table }}$, likewise, the instrument used is appropriate and feasible to be forwarded to the next test. Testing for normality using Kolmogorov Smirnov 
obtained significance greater than 0.50 and thus declared normal. Multicollinearity testing obtained tolerance values $<1$ and VIF $<10$ so that it was concluded there was no interference with multicollinearity. Autocorrelation testing obtained the value of Durbin-Watson at an interval of $1.550-2.460$, thus this regression model does not have autocorrelation. Heteroskesdastisitas test with the Glejser test obtained a significance value greater than 0.05 so it was concluded that there was no interference with heteroscedasticity.

\section{RESULT AND DISCUSSION}

\section{Descriptive Analysis}

The criteria of the object under study are based on the respondent's response to the item questions about the of embandedness social-economic status variables (X1), self-control (X2) and student consumptive behavior (Y) as follows:

Table 1.

Descriptive Score of Respondents' Answers

\begin{tabular}{l|r|r|r|r|r}
\multicolumn{7}{c}{ Descriptive Statistics } & & \\
& N & Minimum & Maximum & Mean & Std. Deviation \\
\hline $\begin{array}{l}\text { Embandedness Socio-Economic Status } \\
\text { (X1) }\end{array}$ & 73 & 32 & 47 & 38.25 & 3.770 \\
\hline Self Control (X2) & 73 & 30 & 49 & 38.75 & 4.459 \\
\hline Student Consumptive Behavior (Y) & 73 & 31 & 46 & 39.32 & 3.605 \\
\hline Valid N (listwise) & 73 & & & & \\
\hline
\end{tabular}

The embeddedness of the socio-economic status results obtained a minimum variance score of 32 and a maximum score of 47 and a ratting mean score of 38.25 and a standard deviation level of 3.770. The self-control data obtained the results of a minimum variance score of 30 and a maximum score of 49 and a ratting mean score of 38.75 and a standard deviation level of 4.459. Data on students' consumptive behavior obtained a minimum variance score of 31 and a maximum score of 45 and a ratting mean score of 39.32 and a standard deviation level of 3.605.

\section{Verification Analysis}

Verification analysis is intended to determine the magnitude of the influence and analyze the significance of the influence. In this analysis carried out on the influence of two independent variables on the dependent variable. partially or simultaneously.

This multiple regression test is intended to find out how big the influence of the variables $\mathrm{X} 1$ and $\mathrm{X} 2$ on the $\mathrm{Y}$ variable. In this study the embandedness of socio-economic status (X1) and self-control (X2) on the consumptive behavior of students (Y). The following are the results of processed regression data with SPSS version 26 which can be seen in the following table: 
Table 2.

Results of Multiple Regression Processing Variables Embandedness Socio-Economic Status (X1) and self-control (X2) Against students' consumptive behavior (Y)

\begin{tabular}{|c|c|c|c|c|c|}
\hline \multirow[b]{3}{*}{ Model } & \multicolumn{2}{|c|}{ Coefficients $^{a}$} & \multirow{3}{*}{$\begin{array}{c}\text { Standardized } \\
\text { Coefficients } \\
\text { Beta }\end{array}$} & \multirow[b]{3}{*}{$\mathrm{t}$} & \multirow[b]{3}{*}{ Sig. } \\
\hline & \multicolumn{2}{|c|}{$\begin{array}{l}\text { Unstandardized } \\
\text { Coefficients }\end{array}$} & & & \\
\hline & $\mathrm{B}$ & Std. Error & & & \\
\hline $1 \quad$ (Constant) & 11.023 & 3.208 & & 3.436 & .001 \\
\hline $\begin{array}{l}\text { Embandedness Socio-Economic } \\
\text { Status (X1) }\end{array}$ & .410 & .093 & .429 & 4.416 & .000 \\
\hline Self Control (X2) & .325 & .079 & .402 & 4.143 & .000 \\
\hline
\end{tabular}

a. Dependent Variable: Student Consumptive Behavior (Y)

Based on the results of the regression calculations in the above table, the regression equation $\mathrm{Y}=11.023+0.410 \mathrm{X} 1+0.325 \mathrm{X} 2$ can be obtained

A constant value of 11,023 means that if the variable embandedness of socio-economic status (X1) and self-control (X2) does not exist then there is a value of student consumptive behavior $(\mathrm{Y})$ of 11,023 points. A value of 0.410 is interpreted if the constant is constant and there is no change in the variable self-control (X2), then every 1 unit change in the Embandedness variable of social economic status (X1) will result in a change in student consumptive behavior $(\mathrm{Y})$ of 0.410 points, a value of 0.325 is interpreted if the constant is constant and there is no change in the embandedness of socio-economic status variable (X1), then every 1 unit change in the self-control variable (X2) will result in a change in the consumptive behavior of students (Y) of 0.325 points.

Analysis of the coefficient of determination is intended to determine the percentage of the contribution of influence between the independent variables on the dependent variable both partially and simultaneously), in this study the variable Embandedness Socio-Economic Status (X1) and self-control (X2) on the consumptive behavior of students (Y). Here are the results of the calculation of the coefficient of determination, as follows:

Table 3

Results of Partial Determination Coefficient Analysis Between Embandedness of SocioEconomic Status (X1) Against Consumptive Behavior of Students (Y)

\begin{tabular}{|c|c|c|c|c|}
\hline \multirow[b]{2}{*}{ Model } & \multicolumn{2}{|c|}{ Model Summary } & & \multirow[b]{2}{*}{$\begin{array}{l}\text { Std. Error of the } \\
\text { Estimate }\end{array}$} \\
\hline & $\mathrm{R}$ & R Square & $\begin{array}{l}\text { Adjusted R } \\
\text { Square }\end{array}$ & \\
\hline 1 & $.646^{\mathrm{a}}$ & .417 & .409 & 2.771 \\
\hline
\end{tabular}

Based on the test results in the table above, an R-Square value or determination of 0.417 is obtained, this shows that the contribution of the influence between embandedness of socioeconomic status to student consumptive behavior is $41.7 \%$, while the remaining $58.3 \%$ is influenced by other factors not researched. 
Table 4

Partial Determination Coefficient Analysis Results Between Self-Control (X2) Against Consumptive Behavior of Students (Y)

\begin{tabular}{|c|c|c|c|c|}
\hline \multicolumn{5}{|c|}{ Model Summary } \\
\hline Model & $\mathrm{R}$ & R Square & $\begin{array}{l}\text { Adjusted R } \\
\text { Square }\end{array}$ & $\begin{array}{l}\text { Std. Error of the } \\
\text { Estimate }\end{array}$ \\
\hline 1 & $.634^{\mathrm{a}}$ & .402 & .393 & 2.808 \\
\hline
\end{tabular}

a. Predictors: (Constant), Self Control (X2)

Based on the test results in the table above, an R-Square value or determination of 0.402 is obtained, this shows that the contribution of influence between self-control to the consumptive behavior of students is $40.2 \%$, while the remaining $59.8 \%$ is influenced by other factors not examined.

Table 5

Results of Simultaneous Determination Coefficient Analysis Between Embandedness SocioEconomic Status (X1) and Self-Control (X2) Against Student Consumptive Behavior (Y)

\begin{tabular}{ll|l|c|c} 
& \multicolumn{3}{c}{ Model Summary } \\
Model & $\mathrm{R}$ & R Square & Adjusted R & Std. Error of the \\
Square & Estimate \\
\hline 1 & $.730^{\mathrm{a}}$ & .532 & .519 & 2.501 \\
\hline a. Predictors: (Constant), Self Control (X2), Embandedness Socio-Economic Status (X1)
\end{tabular}

Based on the test results in the table above, an R-Square value or determination of 0.532 is obtained, this shows that the contribution of the influence between embandedness of socioeconomic status and simultaneous self-control on the consumptive behavior of students is $53.2 \%$, while the remaining $46.8 \%$ influenced by other factors not examined.

To test the hypothesis of the embandedness of socio-economic status (X1) and self-control (X2) on the consumptive behavior of students (Y), it was performed with a statistical test $t$ (partial test).

The results of data processing using SPSS version 26, with the following results: Table 6.

T-Test Results for the Embandedness Socio-Economic Status Variable (X1)

\begin{tabular}{|c|c|c|c|c|c|c|}
\hline \multirow{3}{*}{\multicolumn{2}{|c|}{ Model }} & \multicolumn{3}{|c|}{ Coefficients ${ }^{a}$} & \multirow[b]{3}{*}{$\mathrm{t}$} & \multirow[b]{3}{*}{ Sig. } \\
\hline & & \multicolumn{2}{|c|}{$\begin{array}{l}\text { Unstandardized } \\
\text { Coefficients }\end{array}$} & \multirow{2}{*}{$\begin{array}{c}\text { Standardized } \\
\text { Coefficients } \\
\text { Beta }\end{array}$} & & \\
\hline & & B & Std. Error & & & \\
\hline 1 & (Constant) & 15.687 & 3.328 & & 4.713 & .000 \\
\hline & $\begin{array}{l}\text { Embandedness Socio- } \\
\text { Economic Status (X1) }\end{array}$ & .618 & .087 & .646 & 7.133 & .000 \\
\hline
\end{tabular}

a. Dependent Variable: Student Consumptive Behavior (Y)

Based on the test results in the above table, the value of $t_{\text {count }}>t_{\text {table }}$ or $(7.133>1.994)$ is also strengthened by the value of $\rho$ value $<\operatorname{Sig} .0 .05$ or $(0,000<0.05)$. Thus, $\mathrm{H} 0$ is rejected and $\mathrm{H} 1$ is accepted, this shows that there is a positive and partially significant effect between embandedness of socio-economic status on the consumptive behavior of students 
Table 7.

T-Test Results for Self Control Variables (X2)

Coefficients ${ }^{\mathrm{a}}$

\begin{tabular}{|c|c|c|c|c|c|c|}
\hline \multirow{2}{*}{\multicolumn{2}{|c|}{ Model }} & \multicolumn{2}{|c|}{$\begin{array}{l}\text { Unstandardized } \\
\text { Coefficients }\end{array}$} & \multirow{2}{*}{$\begin{array}{c}\text { Standardized } \\
\text { Coefficients } \\
\text { Beta }\end{array}$} & \multirow[b]{2}{*}{$\mathrm{t}$} & \multirow[b]{2}{*}{ Sig. } \\
\hline & & B & Std. Error & & & \\
\hline & (Constant) & 19.454 & 2.895 & & 6.721 & .000 \\
\hline & Self Control (X2) & .512 & .074 & .634 & 6.906 & .000 \\
\hline
\end{tabular}

a. Dependent Variable: Student Consumptive Behavior (Y)

Based on the test results in the table above we get the value of $t_{\text {count }}>t_{\text {table }}$ or (6.906>1.994), it is also strengthened by $\rho$ value $<$ Sig. 0.05 or $(0,000<0.05)$. Thus, $\mathrm{H} 0$ is rejected and $\mathrm{H} 2$ is accepted, this shows that there is a positive and partially significant effect between self-control on student consumptive behavior.

To test the influence of the embandedness of socio-economic status variable and simultaneous self-control on the consumptive behavior of students at the MA Khazanah Kebajikan Ciputat was performed with a statistical test F (simultaneous test) with a significance of $5 \%$.

Table 8.

Simultaneous Hypothesis Results (F-Test)

\begin{tabular}{|c|c|c|c|c|c|c|}
\hline & 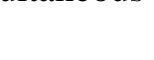 & & NO & & & \\
\hline & & Sum of Squares & df & Mean Square & $\mathrm{F}$ & Sig. \\
\hline 1 & Regression & 497.985 & 2 & 248.993 & 39.814 & $.000^{\mathrm{b}}$ \\
\hline & Residual & 437.768 & 70 & 6.254 & & \\
\hline & Total & 935.753 & 72 & & & \\
\hline
\end{tabular}

a. Dependent Variable: Student Consumptive Behavior (Y)

b. Predictors: (Constant), Self Control (X2), Embandedness Socio-Economic Status (X1)

Based on the test results in the above table, the calculated $F_{\text {count }}>F_{\text {table }}$ or $(39.814>2.740)$ is also strengthened by the $\rho$ value $<$ Sig. 0.05 or $(0,000<0.05)$. Thus, $\mathrm{H} 0$ is rejected and $\mathrm{H} 3$ is accepted, this shows that there is a positive and significant effect simultaneously between embandedness of socio-economic status and self-control on the consumptive behavior of MA Khazanah Kebajikan Ciputat students.

\section{CONCLUSION}

Based on the results of the study of embandedness socio-economic status has a positive and significant effect on the consumptive behavior of students with a magnitude of influence of $41.7 \%$. Self-control has a positive and significant effect on student consumptive behavior with a magnitude of influence of $40.2 \%$. Embandedness socio-economic status and self-control have a positive and significant effect on the consumptive behavior of students with the regression equation $\mathrm{Y}=11,023+0.410 \mathrm{X} 1+0.325 \mathrm{X} 2$. The higher the embandedness of socio-economic status and self-control, the consumptive behavior of students will also increase. The amount of influence is $53.2 \%$ while the remaining $46.8 \%$ is influenced by other factors. Hypothesis testing obtained the value of $\mathrm{F}$ count $>\mathrm{F}$ table or $(39.814>2.740)$, it is also strengthened with a probability of $0,000<0.05$. Thus $\mathrm{H} 0$ is rejected and $\mathrm{H} 3$ is accepted. This means that there are positive and significant simultaneous influences between embandedness of socio-economic 
status and self-control on the consumptive behavior of students at the MA Khazanah Kebajikan Ciputat

\section{REFERENCES}

Anggraini, R. T., \& Santhoso, F. H. (2017). Hubungan antara Gaya Hidup Hedonis dengan Perilaku Konsumtif pada Remaja. Gadjah Mada Journal of Psychology (GamaJoP), 3(3), 131-140.

Anggraini, R. T., \& Santhoso, F. H. (2019). Hubungan antara Gaya Hidup Hedonis dengan Perilaku Konsumtif pada Remaja. Gadjah Mada Journal of Psychology (GamaJoP). https://doi.org/10.22146/gamajop.44104

Anisa, R. N. (2017). Psikologi Remaja Perkembangan Peserta Didik. psikologi.

Astuti, E. D. (2013). Perilaku Konsumtif dalam Membeli Barang pada Ibu Rumah Tangga di Kota Samarinda. eJournal Psikologi.

Azwar, B. (2013). Analisis Faktor-faktor yang Mempengaruhi Niat Kewirausahaan (Entrepreneurial Intention). Studi Terhadap Mahasiswa Universitas Islam Negeri SUSKA Riau. Jurnal Menara.

Fattah, F. A., Indriayu, M., \& Sunarto. (2018). Pengaruh Literasi Keuangan dan Pengendalian Diri Terhadap Perilaku Konsumtif Siswa SMA Muhammadiyah 1 Karanganyar. Jurnal Pendidikan Bisnis dan Ekonomi (BISE).

Hartati, S., Martini, R., \& Winarko, H. (2019). Pengaruh Kecanduan Game Online Terhadap Perilaku Konsumtif Siswa Pengguna Game Online. Jurnal Riset Terapan Akuntansi.

Haryani, I., \& Herwanto, J. (2015). Hubungan Konformitas dan Kontrol Diri Dengan Perilaku Konsumtif Terhadap Produk Kosmetik pada Mahasiswi. Jurnal Psikologi UIN Sultan Syarif Kasim Riau.

Hasanah, U. (2007). Hubungan Antara Interaksi Teman Sebaya dan Konsep Diri dengan Perilaku Konsumtif Pada Remaja Putri. Skripsi thesis, Universitas Muhammadiyah Surakarta.

Kanserina, D. (2015). Pengaruh Literasi Ekonomi dan Gaya hidup Terhadap Perilaku Konsumtif Mahasiswa Jurusan Pendidikan Ekonomi Undiksha 2015. Pengaruh Literasi Ekonomi dan Gaya Hidup Terhadap Perilaku Konsumtif Mahasiswa Jurusan Pendidikan Ekonomi Undiksha 2015.

Mulyadi, M. (2018). Strategi Pemerintah Dalam Penanganan Kemiskinan Dan Kesenjangan. Pusat Penelitian Badan Keahlian DPR RI.

Samio, S. (2018). Aspek - Aspek Pertumbuhan Dan Perkembangan Peserta Didik. Best Journal (Biology Education, Sains and Technology). https://doi.org/10.30743/best.v1i2.791

Sari, C. A. (2015). Perilaku Berbelanja Online di Kalangan Mahasiswi Antropologi Universitas Airlangga. Jurnal Antro Unair.

Sebayang, J., Yusuf, M., \& Priyatama, A. N. (2011). Hubungan Antara Body Image Dan Konformitas dengan Perilaku Konsumtif Pada Siswi Kelas XI SMA Negeri 7 Surakarta. Jurnal Psikologi.

Sohaimi, M. S. (2011). Pembangunan Sosio-Ekonomi Ummah: Satu Mujahadah. Utusan 
Malaysia.

Suminar, E., \& Meiyuntari, T. (2016). Konsep Diri, Konformitas dan Perilaku Konsumtif pada Remaja. Persona:Jurnal Psikologi Indonesia. https://doi.org/10.30996/persona.v4i02.556

Sunarsi, D., \& Kusjono, G. (2019). Pengaruh Lingkungan Kerja Non Fisik, Konflik Dan Turn Over Intention Terhadap Produktivitas Kerja Karyawan Pada CV. Usaha Mandiri Jakarta Selatan. Jurnal Ekonomi Efektif, 1(3).

Suparmin, M. (2012). Makna Psikologi Perkembangan Peserta Didik. Ilmiah SPIRIT.

Vyas, S., \& Kumaranayake, L. (2006). Constructing socio-economic status indices: How to use principal components analysis. Health Policy and Planning. https://doi.org/10.1093/heapol/czl029

Wati, M. Y., \& Suyanto, T. (2016). Faktor yang Mendrong Perilaku Konsumtif Siswa SMA di Surabaya. Kajian Moral dan Pendidikan.

Zaroh, S., \& Lukitianingsih, R. (2014). Penerapan Konseling Behavioral dalam Mengurangi Kecenderungan Perilaku Konsumtif Siswa Kelas X Akutansu 4 SMK Dr. Soetomo Surabaya. Jurnal BK Unesa. 